\title{
Devotional Foundations of Earthly Sovereignty: Conceptualizing Sovereignty and the Role of Devotion in Narrative Political Theology in Premodern India
}

\author{
Caleb Simmons (iD)
}

check for updates

Citation: Simmons, Caleb. 2021. Devotional Foundations of Earthly Sovereignty: Conceptualizing Sovereignty and the Role of Devotion in Narrative Political Theology in Premodern India. Religions 12: 911. https://doi.org/10.3390/rel12110911

Academic Editor: Jeffery D. Long

Received: 14 September 2021

Accepted: 17 October 2021

Published: 21 October 202

Publisher's Note: MDPI stays neutral with regard to jurisdictional claims in published maps and institutional affiliations.

Copyright: (C) 2021 by the author. Licensee MDPI, Basel, Switzerland. This article is an open access article distributed under the terms and conditions of the Creative Commons Attribution (CC BY) license (https:/ / creativecommons.org/licenses/by/ $4.0 /)$.
Department of Religious Studies and Classics, University of Arizona, Tucson, AZ 85721, USA; calebsimmons@arizona.edu

\begin{abstract}
The central premise of this article is that narrative literature from premodern India can give us insights into the ways that sovereignty was conceptualized within broader cosmological structures, creating what has been called "political theology" in other contexts. Looking to narratives for theology can give us particular insights into a tradition's self-description. It is through narratives that Indian kings and their courts were able to describe the intentional-agential worlds of political hierarchies on a cosmic scale and situate themselves within this broader structure. This article, therefore, examines narratives from Purānas, particularly the Viṣnu Purāna and the Dēvī Māhātmya, and dynastic foundational stories and genealogies from Karnataka found in vamśāvalis and epigraphic praśastis, using a twelfth-century Western Ganga inscription as an example, to see the political theologies from the premodern courts of India as they are articulated and performed in and between the realms of the divine and on Earth. After an examination of these materials, this article offers a new model to explain how premodern courts viewed their sovereignty vis-à-vis other divine and earthly sovereigns and how they understood the constitution, transfer, and diffusion of sovereignty throughout this cosmic spectrum of divine and earthly royalty through devotion and giving.
\end{abstract}

Keywords: India; kingship; sovereignty; devotion; Purana; Jainism; Hinduism; Puja; ritual

\section{Introduction}

Looking to narratives for theology, what has been called "narrative theology" in other contexts, can give us particular insights into a tradition's self-description (Frei 1993, pp. 94-116; Flueckiger 2017). The central premise of this article is that the methodology of narrative theology can be expanded, particularly within the study of premodern India, to give us insights into the ways that sovereignty was conceptualized; to put it another way, how narratives created and articulated a theology of kingship, or what has been called "political theology" in the European context. It is through narratives that kings and their courts were able to describe the "intentional-agential worlds" of political hierarchies on a cosmic scale and situate themselves within this broader structure (Frei 1993, p. 119). To see a full picture of this narrative political theology and how it extended throughout the subcontinent, we must bridge several related genres of literature that describe how sovereigns are elected by the divine and how sovereignty is perpetuated through acts of devotion. In this article, I compare accounts from the Purānic traditions and royal genealogies (praśasti, vaṃśāvalis, etc.) to understand the broader theories contained within their analogous narrative constructions of initial sovereignty for celestial rulers and progenitors of earthly royal lineages. By looking into narratives from Purānas and dynastic foundational stories and genealogies, we can see the political theologies from the premodern courts of India as they are articulated and performed in the realms of the divine and on Earth (cf. Flueckiger 2017). These materials present a fuller picture of Indian political theology in which the narrated worlds reflect the political realities within which these political agents envisioned themselves. Therefore, in narrative texts, we can see the ways that premodern 
courts viewed their sovereignty vis-à-vis other divine and earthly sovereigns and how they understood the constitution, transfer, and diffusion of sovereignty throughout this cosmic spectrum of divine and earthly royalty.

In this article, I am interested in how sovereignty is conceptualized in the premodern period, but my primary focus is the theory of kingship that grew out of the Gupta period (see Willis 2009) and developed during the long medieval period. During this period of just over a millennium, the Purānic worldview dominated much of the discourse around kingship, and eulogies of kings and their lineages were increasingly recorded (Ali 2000a, p. 170). In particular, this article seeks to investigate how Indic traditions (I use this term to encapsulate what we now commonly call Hindu and Jain traditions) make sense of the origins of sovereignty, the transfer of that sovereignty from one dynasty to the next, the authority by which a ruler claims that sovereignty, and how, once sovereignty is assumed, it is diffused over time and space via lineage succession and through devotional rituals. ${ }^{1}$ Therefore, I examine narratives from Purānas, particularly the Viṣnu Purāna and the Dēvi Māhātmya, and dynastic foundational stories and genealogies from Karnataka found in vamśávalis and epigraphic praśastis, using a twelfth-century Western Ganga inscription as an example, in order to understand the origins, transfer, and diffusion of sovereignty and its sway.

To foreshadow the conclusions from my analysis below, I suggest that premodern Indic sovereignty was a continuum or spectrum along which a grand political hierarchy was constructed, starting with the divine overlord at the top and trickling down and out through various levels of territory. By considering both Purānas and foundational narratives of localized kingdoms found in vamiśāvalis and epigraphic praśastis as repositories for political theory and as sources in which political theologies of sovereignty were articulated, I argue that sovereignty in premodern India was constructed through rituals of devotion and was nested and gradated through myriad levels of divine and earthly overlords and subordinates. ${ }^{2}$ The picture of political theology within these texts is amazingly unified. They present an image of sovereignty that originates from the divine overlord, who is the source of all creation, and that is diffused into the various realms of creation/existence. As we will see below, just as the Purānas were articulations of a "universe of bhakti" (Biardeau 1994, pp. 88-91), so too was devotion (bhakti) central in the original institution of earthly sovereignty and all of its subsequent transfers found in Purānic narratives, forming a devotional basis for divine election of sovereigns in Purāṇic political theology (see below for examples). In the foundational narratives in the genealogies of historical kingdoms, this process was mirrored, only localized. In these texts, devotion to a local deity (usually a goddess) serves the impetus for their divine election and their inauguration as local sovereigns. Therefore, when read together, the political theology of premodern India begins to take shape.

At the end of this article, therefore, I present a model of Indian kingship and sovereignty that reflects the grand political theory that is articulated in Purānic and royal genealogical narratives concerning divine, imperial, and local sovereignty (see Figure 2 in conclusion below). In this model, I suggest that sovereignty was transferred, diffused, and renewed through devotional rituals centered on $p \bar{u} j \bar{a}$, in which the concept of exchange, culminating the transfer of blessing and authority (types of prasāala), was paradigmatic. ${ }^{3}$ Sovereign power was transferred from the divine overlord to the earthly sovereign, and that same sovereign power was further diffused throughout the territory in analogous rituals of "honor-gifting" between earthly sovereigns and their subordinate kings. This network, however, is not simply one of direct diffusion; for, indeed, local sovereignty was transferred and diffused through local divine sources who elect and authorize local rulers to rule over their kșetra, the local sacred field of divine power.

When we look to narrative literature, such as Purānas, implicit in these sources is a systematic and comprehensive political theology that articulates (a) the origins of sovereignty on a cosmic level, (b) how sovereignty is constituted and shared from divine overlord to divine subordinates, (c) how devotional practices function in the process of 
its variegation, transference, and renewal, and (d) how earthly sovereignty originates in that process. Additionally, this implicit political theology provides an explanation for the role of devotional and ritual practices in the divine election and authorization of rulers. As I will demonstrate toward the end of this article with genealogical narratives from the South Indian (modern day Karnataka) kingdom of the Western Gangas, the narrative political theology of the Purānas is not simply abstracted knowledge, but it is incorporated and enacted in dynastic foundational stories/narratives. As in the Purānic stories, these narratives articulate overlapping constructions of sovereignty, only in these more localized narratives sovereignty is confined within a local context and divine election and royal authority issue from a local source. Reading diverse narrative texts as sources for political theology allows us to take seriously the ways that sovereignty was constituted, articulated, and enacted as premodern Indian courts told the histories of their lineage and their deities; indeed, these types of narrative texts (Purānas, epics, vaṃśāvalis, and praśastis)—and their recitation and performance-were common sources for theology and reflection, as they were consistently produced throughout the long medieval period and into the early modern and colonial periods (Simmons 2020). ${ }^{4}$

\section{Hierarchy of Sovereignty: Reconsidering the Relationship between Divine and Earthy Sovereigns in Premodern Indian Political Theology}

Before we turn our attention to sources of narrative theology, it is important to briefly set the parameters for this study by defining its terminology and placing it within the theoretical context of previous studies on kingship in premodern India. As others have shown (e.g., Stein 1980, 2010; Kulke 1998; Subbarayalu 1982; Chattopadhyaya 1994; Dirks 1993; etc.), within premodern Indian kingship, sovereignty existed in various forms in and through complex relationships of nested and gradated kingdoms that enjoyed differing degrees of autonomy in a variety of administrative, military, economic, and ritual contexts. I leave it to others better suited than myself to continue to refine these models as it relates to the ins and outs of the relationships between chieftains, kings, great kings, and emperors, which I term "earthly sovereigns". Instead, I am interested in the broader hierarchy of sovereignty as conceptualized in the political theology of premodern India, that is how sovereignty is constituted within the king's relationship with the divine and how that sovereignty is transferred from the divine to the king and diffused throughout the territorial domains of the kingdom. It is my contention that sovereignty was not divided into separate spheres - the transcendent realm of divine sovereignty and the immanent realm of earthly sovereignty-but that sovereignty itself is an institution of transcendence and kingship, a dynamic interplay between the transcendent and immanent. In saying that sovereignty is an institution of transcendence, I follow Robert Yelle's reading of Carl Schmitt's wellknown definition of sovereignty- "Sovereign is he who decides on the exception" —in which the "exception" is a miraculous break from normative everyday life that is analogous with "religious moments of transcendence" (Yelle 2010, p. 193; Schmitt 2005, pp. 5, 36). This reading of transcendence and sovereignty is helpful in the case of premodern Indian kingship because it exposes the flaws in many of the assumptions regarding divine kingship by acknowledging that sovereignty at its core is rooted in extra-normativity. By connecting sovereignty with transcendence, we can begin to see the hierarchies of kings and the hierarchies of deities as part of the same political and theological structure.

I am not the first to notice that the hierarchy of kings was a portion of a greater hierarchy of sovereignty in premodern Indian political theology. Indeed, Inden, in his foundational article on the "Hierarchies of kings in early modern India", argues that the social structure of kingship is the lower portion of a larger hierarchical system: "[T]he cosmomoral order created and maintained by a Vaiṣnava or Śaiva king of kings was a very specific ensemble of relations among a hierarchy of lords and their domains. The highest level in this hierarchy was itself a hierarchy of gods" (Inden 1981, p. 103). Inden's focus for the majority of the article, however, is the arrangement of kings in the imperial court through which this hierarchy was "concretely, dramatically and visibly enacted" (1981, 
p. 103). Toward the end of the essay, however, Inden connects the conceptualization of hierarchy within the royal assembly to the cosmological structure found in the Purānas. He demonstrates that the arrangement of kings in imperial courts is analogous in structure with the celestial realm. ${ }^{5}$ The celestial kingdom is centered around the palace of the divine overlord (for Inden either Viṣnu or Śiva) and extends through different realms (varșa) of the cosmos, one of which was Bhāratavarșa or India. Indeed, both spatially and politically, the two kingdoms mirror one another but on differing scales, with ritual homology connecting the earthly sovereign to the divine overlord (see Figure 1). It is this very overlap that has caused many scholars to describe these gradations of territory in terms of macro- and micro-scales.
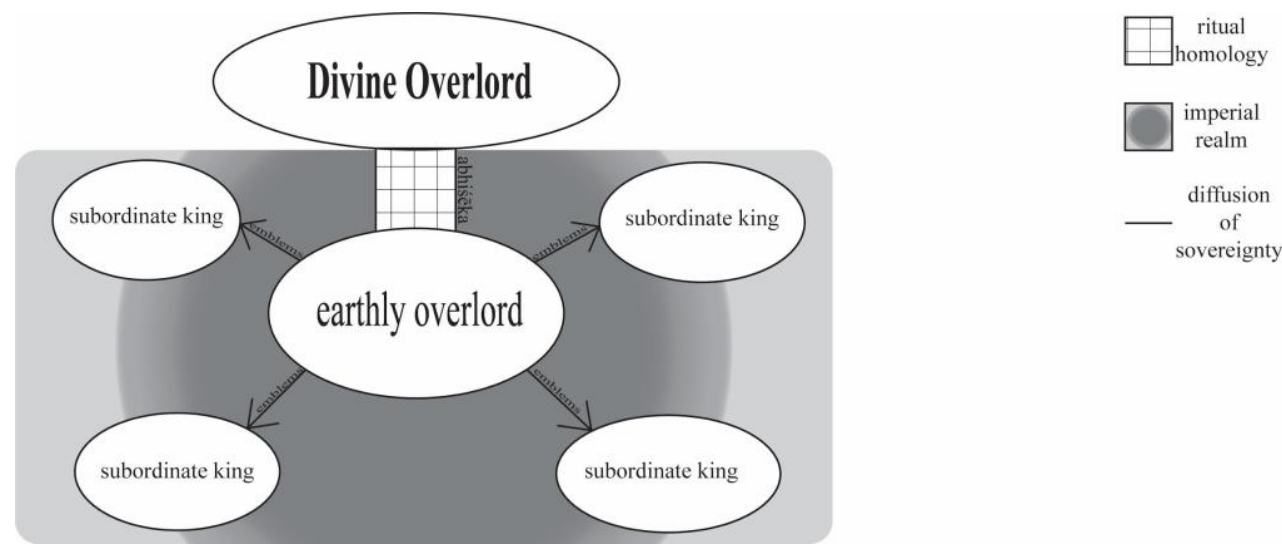

Figure 1. Model of the diffusion of authority and sovereignty based on Dirks, Inden, Kulke, and Stein ${ }^{6}$.

While this presentation of kingship made by Inden and others is helpful in many cases, it often obscures our understanding of political theology by conceptually separating cosmological and earthly realms instead of placing them within a continuum of greater and lesser territories and domains of sovereignty. ${ }^{7}$ I, however, wish to highlight the broader network of divinity and earthly sovereignty. As I argue in this article, through ritualized devotion, a king submitted to the suzerainty of the cosmic ruler and inserted himself in the ordered domains of heaven after which his subordinates were similarly ordered. The emperor's kingdom, therefore, was to the celestial overlord what the lesser kingdoms and sāmantas were to the emperor-part of one larger network of gradated territories in which smaller realms of sovereignty were nested (see Figure 2 in the Conclusions).

Understanding this relationship between divine and earthly sovereignty is critical if we are to make sense of how earthly sovereignty is authorized and how premodern Indian theorists understood its transfer and diffusion from overlord to subordinate over space via exchange and conquest and through time via dynastic continuity. Indeed, within the political theology from the Purānic tradition, and in its cosmologies more generally, sovereignty is shown to emanate from the ultimate deity, who presides over creation. This initial sovereignty was diffused through creation and at various levels, including the creation of other deities, epoch-ruling Manus, and epic and legendary kings who are associated with the Sun and Moon, both celestial kings (see Balkaran 2020). The transition of sovereignty to the Manus and the epic rulers found in the Purānas form the prototypes whereby sovereignty can be transferred from its divine origin, i.e., the divine overlord, to earthly sovereigns charged with ruling on earth, diffused $p \bar{u} j \bar{a}$-like rituals of exchange. It is my contention that the sovereignty in premodern India is constituted and enacted through devotional rituals. It is through these rituals, particularly the reciprocal giving and receiving of implements imbued with the sovereign/divine sway (i.e., royal prasāda), that the initial transfer of sovereignty is re-enacted and through which it is continually renewed and diffused. In order to understand how sovereignty is conceptualized as descending from the divine, let us now turn to narratives in which the transfer and diffusion of sovereignty 
is depicted in the Purānas and how that relates to the localization of sovereignty in the foundation myths of local kingdoms.

\section{Devotion and the Creation of Subordinate Sovereignty in the Purānas}

While the most obvious source for information about kingship might seem to be texts that explicitly discuss the theories of state and rule, such as dharmaśasstras and arthaśāstras, the literary texts that give us the most information about the political theology of premodern Indian courts are the narrative materials found in the Purannas. It is in these texts that we see explicit discussions of the origins of sovereignty, its transfer from one lineage to the next through divine election, and its diffusion through the divine and earthly lineages of rulers. Additionally, we know that the Purānas were the sources that the ministers of the court consulted regarding matters of royal ritual and dynastic continuity. ${ }^{8}$

Central to the Purānic understanding of kingship is the sovereignty of the Manus, who are commissioned to rule over epochal intervals of time (manvantara) and are the progenitors of all earthly beings but are especially connected to the creation of kșatriyas (i.e., "rulers"). ${ }^{9}$ The narrative of the first Manu is somewhat standardized amongst many Purānas, in which we find the initial creation of subordinate sovereignty in the birth of the first Manu, who is born from the mind of Brahmā and is therefore called Svāyambhu (self-born) Manu. ${ }^{10}$ The Svāyambhu Manu is a replication of Brahmā and is the source of the creation of the worlds and its inhabitants through the proliferation of his progeny. It is within his genealogy that the Purannic narrative of the institution of earthly sovereignty and the creation of political territory and boundaries is given. The narrative relates the transition from the direct sovereignty of the gods during the Satya Yuga ("period of truth," the first of the four-part cycle of Indian time) to gradated sovereignty of divine and earthly rulers in the Trētā and subsequent yugas.

The institution of earthly sovereignty with the reign of Pṛthu is given in many Purānas in the context of the lineage of Svāyaṃbhu Manu (e.g., Bhāgavata, Vāyu, Viṣnu Purānas). Here, I will relate the narrative as told in the thirteenth chapter of Book One of the Viṣnu Purāna as the text describes the genealogy of the Svāyambhu Manu prior to the creation of earthly rulers. The Viṣnu Purāna explains that from the lineage of the Svāyambhu Manu, an evil cosmic ruler named Vena had arisen. Due to his evil nature, Vena banned all sacrifice. When approached by the gods and sages, who intended to impress upon him the importance of the sacrificial ritual, Vena in turn questioned the authority of Viṣnu and forbade the sages to worship him. This infuriated the sages, who immediately attacked the ruler and beat him to death with blades of kuśa grass. At this point, the rssis realized that they were without a ruler and that the cosmos would accordingly descend into chaos; so, they rubbed Vena's corpse's right hand and from that hand Prthu emerged. ${ }^{11}$ At the moment of this appearance, royal implements including Śiva's bow fell down from heaven, all beings rejoiced, and Vena was released from hell and ascended to the realm of the ancestors. At that point, Brahmā appeared and recognized that Pṛthu had been chosen by Viṣnu to be the sovereign over the entire Earth (cakravartin) because Pṛthu's right hand was marked with Viṣnu's, the cosmic overlord's, emblem, the discus, his sign of divine election. ${ }^{12}$ At this pronouncement, Brahmā conducted the rituals of coronation. After being crowned king, all beings showered Pṛthu with affection $(r \bar{a} g a)$, and so he accepted as his official title "rāja," thus providing a folk etymology for the title at the inauguration of earthly sovereignty. ${ }^{13}$ After his coronation ceremony, Prthu began patronizing rituals and giving grants to brahmins. Additionally, he set out to conquer the Earth goddess Prrthvī and pursued her in her form as a cow throughout the cosmos. Finally, the Earth submitted to his sovereignty and accepted his name as her own (i.e., Pṛthu $\rightarrow$ Prthvī). Prrthu leveled the Earth's landscape by setting the mountains together and on top of one another, defined boundaries and territories, and instituted agriculture and highways for trade. Further along in the text (Book 1 Chapter 22), the Viṣnu Purāna details the institution of subordinate sovereignty within the seven realms of the cosmos, including Earth, explaining that all sovereigns were authorized by Viṣnu, who is the supreme overlord and of whom 
all sovereignty is only a portion, thereby framing earthly sovereignty within a broader hierarchy of divine and earthly overlords and subordinates.

Within this narrative, there are several important features through which sovereignty is defined: devotion/piety, authority symbolized through emblematic prasāda, and conquest. I will return to these in more depth below in my discussion of local foundational myths, but here I will briefly highlight their importance for understanding how this narrative reflects a broader Purānic political theology. First, the entire narrative is framed through devotion and piety, or the lack thereof. When the evil ruler Vena banned the Vedic sacrifice, the gods and sages were willing to reason with the ruler; however, when he prohibited them from worshiping the divine overlord, they immediately jump him with kuśa grass, perhaps demonstrating the power of ritual material culture in the matter of royal authorization. Further, Prthu proves his worthiness to rule through piety and devotion by inaugurating his rule with rituals and patronage, displaying his Vaisnava devotion through practice. Second, the narrative displays the divine election of the sovereign through the mark of the discus on Prrthu's hand. In this story, it is Brahmā who acts as the ritualist and recognizes the mark of the divine authority and Prthu's chosen-ness. In this story, the discus, an emblem of Visnu, who is recognized as the divine sovereign in the narrative, had been placed onto Pṛthu as a blessed residual of Viṣnu's authority, a permanent form of cosmic prasāda implanted unto a universal ruler. It is not surprising that the mark of election is Viṣnu's emblem, the discus, as it is a common reference to his divine sovereignty and was used throughout premodern India as insignia for kings and their kingdoms. Indeed, the discus was an emblematic corollary for royal consecration rituals (rājasūya) going back as far as the fifth-century CE Gupta Empire that was fully developed in the Purānic corpus (Willis 2009, p. 68). The discus is not only a symbol of sovereignty, but it is also a weapon that relates kingship to military action, which brings me to the third major aspect of sovereignty in this narrative: conquest. ${ }^{14}$ At the end of the Prthu story, we see the centrality of conquest in sovereignty, as Pṛthu forces Pṛthvī to submit to his authority. Additionally, we see that along with this conquest, cultivation of the landscape and the demarcation of new territorial boundaries was necessary to bring the newly subdued lands under one's royal authority. Thus, in the Prthu narrative, we see an articulation of political theology in which sovereignty is created through proper devotion, is authorized by divine election that is recognized by a ritual professional, and is intimately related to conquest and the cultivation of new territories-all of which are common in the foundational narratives of premodern South Indian kingdoms discussed below.

Additionally, in their self-styled requirements (pañcalakṣaṇa), (mahā-) Purānas are required to make explicit reference to the subsequent Manus that have ruled over the manvantaras through the ensuing cycles of existence. Most Purānas are quite clear, however, that all Manu cycles necessarily unfold the same way and earthly kingship is instituted in the Trētā Yuga when kṣatriyas are born from the contemporaneous Manu and occupy the various realms of creation (e.g., Vāyu Purāna 31.40-41, Mārkaṇ̂̄ẹa Purāna 53.10). Additionally, it is from these Manus that the epic and legendary kings from the Solar and Lunar lineages are born (e.g., Viṣnu Purāna Book 4; see Pargiter 1913). It should come as no surprise that claims to these lineages in Indian royal genealogies form a baseline of royal and imperial rhetoric. The rulers of the Manu cycles and the lineages of the earthly sovereigns are intimately connected. Therefore, in premodern India, political theology it is often imperative for the text to develop the relationship between earthly sovereignty and the reign of these subsequent Manus through Purānic narratives. We can see how the sovereignty of the divine overlord, Manus, and earthly rulers are systemized in the Dēvi Māhātmya from the Mārkandēeya Purāna.

The Dēvī Māhātmya is an important Purānic source for narrative political theology because of its significance in royal rituals, such as Navarātri rituals, its ubiquity within premodern and modern courtly libraries, and because it seems to contain the paradigmatic royal devotional world that forms the basis for the foundational narratives that are found in genealogical materials. Throughout the narratives of the Dēvi Māhātmya, the 
text constructs the Goddess as the ultimate overlord of the cosmos who is both the source and the embodiment of sovereignty. The best example of the explicit connection between sovereignty and the Goddess comes from the second chapter of the text at the beginning of the Mahisāanura episode. After Mahisāsura (buffalo-demon) had usurped power from the gods, the Goddess emerged out of their combined luster to grant their wish for the restoration of their sovereignty. Once in her presence, all of the gods gifted their sovereign queen (iśvarī) their emblematic weapons (trident, discus, thunderbolt, etc.). After defeating the demon, she restored their kingship and was praised as the universal sovereign, who protects the three worlds (triloka; see Dēvī Māhātmya 4.25). Finally, she consents to fulfilling the role of their sovereign protector whenever she is praised. This ritual of exchange is reminiscent of the royal rituals analyzed by Dirks (1993, 100ff), in which Vijayanagara emperors gave their imperial sword to their goddess, who, in turn, returned the royal implement imbued with royal power as her prasāda, a ritual exchange that was then mimicked between the emperor and his subordinate kings. While this narrative alone is a strong indication of the text's emphasis on kingship, the Dēvi Māhātmya models the manifestation of the Goddess in this episode on the primordial establishment of earthly sovereignty that had previously been described in the Manusmrti, in which the first king is said to have similarly emerged from the luster of the gods, implicitly connecting kingship with rāja from $\sqrt{ } r \bar{a} j$, "to shine" (Manusmrti 7.3-4). Implicitly, the text is making the argument that the divine power that infuses all sovereigns, including the gods, is none other than the power (śakti) of the Goddess. Additionally, since the Dēvī Māhātmya is clearly alluding to the creation of earthly sovereignty found in the Manusmrti, it also suggests that the transfer of sovereign power can be indirect and mediated through the various levels of sovereign hierarchy with the gods (and their royal accoutrements), acting as conduits for the transfer of sovereign power of the Goddess to flow into earthly rulers. The Dēvi Māhātmya thus goes to lengths to show that the Goddess is the paradigmatic overlord and that it is in her that sovereignty originates and through her and her agents that it is transferred and diffused.

The Dēvī Māhātmya itself is a smaller glorification text that is situated within the broader work of the Mārkandèya Purāna, specifically placed within a discussion about the various rulers of the Manu epochs, and their election to rule over all creation (See Balkaran 2019). ${ }^{15}$ The Dēvī Māhätmya itself serves as the narrative for the divine election of the eighth Manu Sāvarṇi, who was born during the seventh Manu interval of Sarōcișa, in which we see the role of devotion in the transfer of sovereignty from the Goddess, the divine overlord, to Sāvarni Manu. ${ }^{16}$ After the Dễvi Māhātmya opens with a brief allusion to this broader sovereign frame, it transitions to the well-known internal frame story of the king Suratha, the merchant Samādhi, and the sage Mēdhas, who explicates the mythic deeds of the Great Goddess that comprise the bulk of the Dēvi Māhātmya. In the thirteenth chapter of the $D \bar{e} v \bar{\imath} M \bar{a} h \bar{a} t m y a$, the relationship between the Goddess and earthly sovereignty is more concretely connected. After Mēdhas has finished his narration of the mythic deeds of the Goddess, king Suratha pays homage to the sage and proceeds to the riverbank along with Samādhi, where they establish an image of the Goddess, perform $p \bar{u} j \bar{a}$ to her, offering her flowers, incense, and fire, and even performing abhiśek $a$ with water and their own blood. After three years of doing this daily, the Goddess appears before the king and merchant and offers them each a boon (verbal prasāda?). Suratha chooses to have his kingdom restored, and he is granted not only his kingdom in his present life but that he will be reborn as the Manu Sārvani and rule over the entire earth. In this conclusion to the internal frame narrative, as in the main narrative of the text, we see that earthly sovereignty is authorized and bestowed by the Goddess in conjunction with devotional ritual that involves praise and exchange.

In the Purānas, we find narrative articulations of premodern Indian political theology in which we can see the broader hierarchy of divine and earthly overlords and subordinates and how sovereignty originated and is transferred and diffused from the cosmic level and instituted on earth. Additionally, it comes as no surprise given the devotional nature of the 
Purānas that these texts frame sovereignty and its constitution through a devotional/ritual lens. Devotion is the primary cause for the creation of earthly sovereignty with Prthu and the divine election of rulers both within the cosmic Manu intervals and at the local level in the case of Suratha, and in each case, the transfer of sovereignty was aided by the ritual exchange of emblems implements that function similarly to prasāala.

\section{Localizing Sovereignty through Devotion}

A narrative motif, which is similar to the narrative of the devotional transaction between Suratha and the Goddesss in the Dēvi Māhätmya, is commonly found in the foundational stories from premodern South India, especially in southern Karnataka. This motif can be found in inscriptions dating back to at least the twelfth century-with antecedents from the sixth - that have continued through the early modern, modern, and contemporary royal histories of South Indian kings, including the Mysore Woḍeyars (e.g., Ganga, EC VII Sh.4; Hoysala, REC IX Bl.389; Mysore, Śrīmanmahārājavara Vạ̣śāvaḷi) (Simmons 2017). ${ }^{17}$ Broadly speaking, these narratives tell of a heroic man (sometimes brothers) who happened upon a site that is recognized as powerful because of some miracle or odd occurrence. Likewise, the goddess, who resides in that place and from whom the site's power is derived, recognizes the man for his heroism. Then, with the help of the leader of the local devotional sect, the man performs $p \bar{u} j \bar{a}$ (Sanskrit) / pūje (Kannada) to the deity, after which he receives the royal unction and the emblems of the goddess, transforming him from a mere man into a sovereign. In most iterations of this motif, with the aid of the goddess, the new sovereign defeats an evil king, who had previously usurped the kingdom, or subdues another nearby kingdom, after which a capital and temple are established in or near to that sacred site of power where the transfer of sovereignty had taken place. There are a few key elements within this narrative type that help us to understand the constitution of sovereignty and its implicit political theology, especially in light of similar Purānic stories: the relationship between divine election and authorization symbolized by the gifting of emblems, space and sovereignty, and role of conquest in the transfer of sovereignty. But before I turn our attention to these aspects of the narrative, it is important to consider the context and media in which this foundational narrative type first appears.

The earliest extant forms of this motif in the context of historical kings are contained in inscriptions that detail grants of land for brahmins, temples, and mathas that collect the revenue from its yield as tax-free income. ${ }^{18}$ These inscriptions, which were engraved on stones or portable copperplates, functioned as legal records that detailed the reason for the donation, the parameters of exchange, measures of lands and/or kind, the beneficiary, the benefactor, and they recorded upon whose authority the grant was inaugurated. The composition of these inscriptions was relatively standardized beginning with a Sanskrit invocation of the dynasty's deity. This is followed by the eulogy (praśasti) of the ruler that includes his genealogical details with high poetic praise of his lineage and his deeds that is written in either Sanskrit or the vernacular. If the ruler who was making the grant was a subordinate within the broader political order, his details and the details of his lineage were placed below that of the imperial overlord's (e.g., Mysore, REC Vol VI Kr.117). The language employed at each level uses overlapping but gradated terminology denoting the nested forms of sovereignty over the universe, over subordinate kings, and over a limited local sphere (e.g., jagadiśvara, mahārājāadhirāja, mahārāja). Additionally, even from the spatial arrangement of text in the encomia of the deity, overlord, and subordinate king, we begin to see a broad hierarchy being articulated and displayed. After this initial formulaic panegyric, the inscription transitions to the logistical details of the grant. As Inden has pointed out, the perspective of the narrative voice of these different sections changes and is important for thinking about how it functioned as an articulation of broader political theology (1990, pp. 231-33). The first portion of the inscription is written in the voice of an all-knowing narrator, "someone situated between the realm of the gods and the realm of men" (Inden 1990, p. 231). The details of the grant, however, are delivered in the words of the king in the form of an order. ${ }^{19}$ 
The different sections-encomia and the grant details-have different functions, but they work together to show how sovereignty is authorized and enacted. The praśasti acts as a preface to the grant itself, stating the credentials of the king within the political structure. By relating the king's genealogy and the lineage's foundation story, it demonstrates the path through which their sovereignty has been authorized from its initial transfer from the deity through election and devotion and its diffusion through royal lineage. I do not believe that these were meant for a popular or wide audience, nor were they intended to legitimize the rulers in the eyes of their subjects, rivals, or otherwise, but they were a necessary part of this legal document in order to demonstrate the ruler's sovereignty over this matter against claims of arrogation. The grant itself was the enactment or the derogation of that sovereignty. Indeed, the establishment of such a tax-free land grant was one of the most important exceptions to the normative legal system in medieval India. The power to give these grants was directly linked to sovereignty and ruling power and was the ultimate state of exception within the broad political structures (see Schmitt 2005). ${ }^{20}$

When we view these inscriptions as part of legal documentation in which sovereignty is performed through the proclamation of a grant that establishes a state of exception for a religious institution, we can see how narratives of dynastic foundation operated as an articulation of premodern Indian political theology. As important declarations of sovereignty, these narratives were borrowed from dynasty to dynasty as a means to describe a lineage's divine election and the transfer of sovereignty from the previous rulers. Over time, these stories were elaborated upon and expanded as genealogical writing, especially vaṃśāvalis, became a popular courtly literary genre that flourished in the Vijayanagara period (14th-16th centuries CE) and in the period of their successor states (16th-18th centuries $\mathrm{CE}$ ).

\subsection{An Example of the Motif, the Western Ganga Foundation Narrative}

To analyze the devotional nature of sovereignty in the foundational narratives of southern Karnataka, it is helpful to examine an example in which we can see how the narratives express a political theology and how it conveys the importance of divine election, locality, and conquest in the initial transfer of sovereignty from one dynasty to the next. For my discussion, I have chosen to summarize one of the older inscriptions of this type in southern Karnataka from the Western Ganga dynasty that was inscribed in 1122 CE in Kallūrguḍda in the Shimoga District on the occasion of King Nanniya Gañga Permmāḍi Dēva rebuilding the Jain Pațada Tīrtha basadi in Mạ̣dali as a stone structure (EC VII Sh.4). This inscription is one of the longest from the Western Gangas and contains the most detailed account of their lineage ${ }^{21}$ Additionally, the framework of this foundation narrative comes from a Jain context, which hopefully helps to show that this form of situating local sovereignty was a broader phenomenon that transcended sectarian distinctions of what one might now call Hinduism or Jainism. Within this inscription, we can see how sovereignty was localized through devotion and its corresponding exchange.

The text begins with the Sanskrit invocation of the Jain syād vāda doctrine, which it extols as the doctrine (śāsana) of the ruler (nātha) of the three worlds (trailokkya). Next, the inscription switches to Kannada and praises Trailōkyamalla Dēva, the Gañgas' Cālukyan overlord, with the titles mahārājāahirāja (emperor), paramēśvara (supreme lord), and paramabhatțāraka (supreme venerable person). Additionally, the inscription praises Trailōkyamalla Dēva's kingdom, which extends in the four directions for as long as the sun and moon shine. Within these first few lines of the inscription, there are already a few interesting details that show the analogic relationship between sovereignty, divinity, and devotion. In the first invocatory verse, the wording is ambiguous as to whom it is referring when it says the "ruler of the three worlds". Indeed, this could be a reference to a Jina, since the term it uses in the verse is nātha, which is the common suffix within the names of the Tīrthānkaras, but at the same time it could be a reference to the earthly overlord, the Cālukya Trailōkyamalla ("the subduer of the three worlds"). As with many invocations in inscriptions, the language is probably intentionally ambiguous, intended to 
relate a double meaning (ślẹșa). Additionally, the title bhattāraka is the sovereign title that is used later in the inscription to refer to the Tīrthānkara Pārśvanātha and was adopted by Jain Digambara matha leaders as a sign of their sovereignty and the sovereign status of the mathas over which they were leaders. Therefore, by claiming the Câlukya king as the "supreme bhattāaka", it both places him within the realm of Jain sovereignty and at its head. $^{22}$

The text then transitions to the story of the Ganga lineage. The narrative begins in the time of the Jain Tīrthānkara Rṣibha in the city of Ayōdhyā with the mythic king Hariścandra, who ruled from the Ikṣvāku Solar lineage. Hariścandra's son was Bharata, who was unable to have an heir; however, his wife Vijaya Mahādēvi conceived after bathing in the Gangā and gave birth to a son, whom she called Ganigadața ("given by Gañā"). The narrative then jumps ahead to the time of the Tīrthānikara Nēminātha, when the Ganga king Viṣnugupta, who was ruling from Ahicchatra, performed Aindradhvaja ("Indra-flag") $p \bar{u} j \bar{a}$ (Kannada: $p \bar{u} j e$ ) at the time of the Jina's nirvāna. Indra was so pleased by Viṣnugupta's devotion that the deity gifted him his royal elephant Airāvata. To Viṣnugupta two sons were born: Bhagadatta, who was given the Ganga kingdom in Kalinga (Odisha), and Śrīdatta, to whom was given Airāvata and the rest of the kingdom. Upon his coronation, Śrīdatta adopted Airāvata as the insignia (undige) of the Ganga kingdom.

Again, the narrative jumps forward, but this time to the period of Pārśvanātha (here called "Pārśva-bhattāaraka") and the rule of the Gañga king Priyabandhuvarmma. Similar to the story above, at the time when Pārśva was attaining enlightenment (kēvalajñana), Indra had come to the foot of the Jina to perform kêvala pūjā. Simultaneously, Priyabandhuvarmma came out of his devotion (bhakti) to perform his own $p \bar{u} j \bar{a}$. Indra was so pleased by his devotion that he gave Priyabandhuvarmma five ornaments (todage) that would disappear if anyone in his lineage ever broke the faith. Having received this blessing from Indra, the king renamed his capital Vijayapura.

The text then transitions to the narrative of the founding of the Ganga line in southern Karnataka, here called Gangavādi. This narrative begins with the birth of king Padmaprabha. He, similarly to Bharata, was unable to have a son; so, he worshipped the local goddess Śāsana Dēvate, who was the source (kaṇi) of the king's power $(\bar{a} \underline{r}) .{ }^{23}$ Once he had obtained her blessing, he had two sons, who were named Rāma and Lakșmana. After a while, an evil king named Mahīpāla from Ujjain attacked Vijayapura and demanded Indra's ornaments. The threat enraged king Padmaprabha; so, he called his sons and changed their names to Dadiga and Mādhava and sent them away to the south in search for their own kingdom. When they came to Pērūr, they camped next to a Jain caityālaya ("temple") and were filled with devotion (bhakti). After circumambulating the temple three times and singing praises (stutiyisu), they spotted the saint Simhanandi, and after they paid him homage out of their bhakti for the guru, they told him about what had transpired. Simhanandi was obviously impressed because after he heard their story the guru took them under his wing and began to teach them. After a few days of instruction, as they performed her rituals, the goddess Padmāvati appeared before them because of their devotion to her and gave them a sword and the kingdom. As the guru looked on, Mādhava took the sword and sliced a stone pillar in two, after which the saint placed crowns of kannikāra flowers on them, performed the royal unction with grains, gave them his emblem of the peacock fan, along with numerous courtiers, elephants, and horses, and declared them the sovereigns over the entire kingdom of the Gangavādi Ninety-Six Thousand as long as they uphold the Jain doctrine. The inscription then declares that they ruled from the Nandagiri fort in Kuvalāla with the Jina as the lord, victory their companion in battle, and Jain matha as their matha. After this inauguration, they left to conquer the Konkana coast but on the way stopped in Maṇali and erected a Jain caityālaya.

The inscription continues through many more generations, including the loss of the ornaments of Indra during the reign of the Viṣnugōpa, who did not uphold the Jain dharma, up to the contemporaneous king Nanniya Ganga Permmāḍi Dēva. Additionally, it includes several generations of the Hoysala lineage and the lineage of the Ganga gurus 
from Simhanandi to the contemporaneous guru Budhacandra Dēva. The inscription ends with the detail of the grant informing the reader that Nanniya Ganga Permmādi Dēva was renovating the temple first built by Dadiga and Mādhava and renaming it the "coronation temple" (pattada basadi). It then details the lands that were attached to the renovation project and the temple's daily offerings and $p \bar{u} j \bar{a} s$. The inscription concludes with another brief round of encomia of the king in which he and his queen (or royal goddess, pattada $m a h \bar{a} \overline{\bar{e}} \mathrm{v} i$ ) are said to have likewise obtained the boon (of sovereignty) from Padmāvati. ${ }^{24}$

Within the narratives contained in this inscription, which are quite representative of the broader motif in southern Karnataka, we can see many of the same political theological concerns that were present in the Purānic material described above. Therefore, let us now turn to the themes that arise in both narrative genres, namely divine election and authority, situating earthly sovereignty, and the role of conquest in the enactment of sovereign power, specifically as they occur in this royal foundational narrative.

\subsection{Divine Election and Authority}

Within this example of the broader foundational narrative motif found in southern Karnataka, the relationship between the Ganga lineage and its sovereignty is directly connected through divine election and the authority to rule and the transfer of sovereignty that accompanies that election. Additionally, in each case, the impetus for the divine election is through the devotionalism of the Ganga rulers.

Perhaps the most important theme throughout this eulogy of the Ganga lineage is their recurring interactions with the divine through various devotional acts and the subsequent exchange/gifting. At each level of the praśasti, the Ganga ruler that it focuses on displays their devotional virtuosity, which in turn leads to a special gift from a deity, which in every case except one leads to a devotional reaction by the rulers (see Table 1). If we look closely at these interactions, however, we can see two distinct forms of sovereign-divine interaction that need to be more fully explored.

Table 1. Interactions between Ganga rulers and the divine in inscription EC VII Sh.4.

\begin{tabular}{ccccc}
\hline Rulers & Deity & Action & Gift & Reaction \\
\hline Bharata/Mahādēvi & Gañgā & bathing & son & named son “Gañgadatta" \\
Vișnugupta & Indra & $p \bar{u} j \bar{a}$ & Airāvata & accepted Airāvata as insignia \\
Priyabandhu & Indra & $p \bar{u} j \bar{a}$ & 5 ornaments & renamed capital Vijayapura \\
Padmaprabha & Śāsana Dēvate & $p \bar{u} j \bar{a}$ & sons & n/a \\
Daḍiga/Mādhava & Padmāvati & $p \bar{u} j \bar{a}$ & sword/Gañgavāḍi & temple/conquest \\
Nanniya/Mahādēvi & Padmāvati & $?$ & boon & temple renovation \\
\hline
\end{tabular}

From the beginning of the narrative, the reader is informed that the Ganga lineage is not part of an autochthonous dynasty, but that it is rooted in the celestial lineage of the Sun through Ikṣvāku and the epic king Hariścandra. As the genealogy continues, it does not proceed generation by generation, but it jumps form era to era, focusing on the times when Jinas are enlightened or when a Ganga ruler does not have an heir. As different as these situations might seem, they both produce similar crises for the continuity of sovereignty that are overcome with royal devotion (and the text is sure to highlight the bhakti of the kings). When on Earth, the Jina would have been the most perfect human, the embodiment of universal [divine] sovereignty who through their enlightened knowledge has command of all of existence (samsāra) (Babb 1996, p. 5; Cort 2001, p. 43); however, in the absence of a Jina-that is, after they fully cross-over, completely removed from affairs of this or any other realm - there is a theoretical vacuum of sovereignty, which, in Jain and broader Indic political theology, can be filled by a world-conquering sovereign, a cakravartin (Dundas 1991, pp. 178-81; Pierce Taylor 2020). ${ }^{25}$ Indra, the lord of the gods, however, appears at this moment and acts as the mediator, diffusing divine sovereign power back into the earthly ruler (Vị̣nugupta and Priyabandhu) through the gift of emblems (Airāvata and the five ornaments), perhaps implying that these kings of the Ganga line were cakravartins. 
Similarly to the Vijayanagara emperor or the deities in the Manusmrti, Indra is the conduit through which the divine sovereignty is diffused to the earthly subordinate(s) through the gifting of royal emblems. Likewise, in the other cases, namely Bharata and Padmaprabha, the lack of an heir caused a crisis of dynastic and, thereby, sovereign continuity. In both cases, the rulers (or their wives) performed acts of devotion (bathing or $p \bar{u} j \bar{a}$ ) to local goddesses, after which they were rewarded with heirs. Therefore, we see two different responses to two crises in sovereign continuity wherein devotion is the mode of transaction. The first is concerned with the broader hierarchies of sovereignty and the void created by the absence of the divine overlord. In this case, the hierarchy is affirmed, with Indra renewing the Ganga king's sovereign power through the ritual exchange of emblems as a result of a royal $p \bar{u} j \bar{a}$. The second crisis is more local and concerns dynastic continuity through lineage succession. Here, it is not Indra or a Jina who is worshipped, but it is a local goddess, who is able to ensure the continuation of the line. In both cases, however, the inscription assumes that the Ganga king is already sovereign within his own realm and only reflects their previous divine election.

The final narrative of Dadiga and Mādhava is the longest and most important and is the model upon which Nanniya Ganga Permmādi fashions his kingship. The narrative of Dadiga and Mādhava focuses on the establishment of the local dynasty, finally situating the Ganga dynasty within its territory at the time of the inscription. As such, it acts as a proper foundational narrative for the Ganga dynasty and displays the transfer of sovereignty from the local goddess to the Ganga brothers in a region where they have no sovereign authority. Therefore, the narrative gives a glimpse into the conceptualization of divine election and the subsequent transfer of sovereignty that reflects the narrative of Suratha from the Dēvi Māhātmya and many of the other foundational narratives in premodern South India. ${ }^{26}$ As we have seen, the foundational narrative begins with Dadiga and Mādhava being removed from their kingdom. In their travels, they come across the wise guru, who instructs them in the way of the goddess, after which they perform rituals to the goddess, who in turn recognizes their devotion and gives them a kingdom. In both the Purānic model and the local inscription, it is clear that the rulers are elected by the goddess on the basis of their superior devotion and their proper enactment of devotional rituals.

In the inscription, however, we see more closely the ritual of the transfer of sovereignty in which gifting and unction are important features. The entire transaction is modeled after and takes place within the $p \bar{u} j \bar{a}$ ritual. As the brothers worship the goddess, she appears and gives them a sword as prasāda. This sword, as with all prasāda, is charged with the divine surplus of the deity, but in this case, the sword is a royal prasāda through which the sovereignty of the local goddess over that sacred site is transferred to its new rulers. Once this transaction is complete, the guru Simphanandi acts as the elector and acknowledges the ruler's divine election. To inaugurate their sovereignty, the guru crowns Dadiga and Mādhava with flowers and performs the royal unction with grains granting them dominion over the entire territory (samasta dhātri) of the Gangavādi realm (parāurtra), the boundaries of which are clearly demarcated in the text. This narrative description of divine election and the transfer of sovereignty gives us a fuller exposition on the political theology of the Ganga court in which devotion and its enactment through $p \bar{u} j \bar{a}$ were central in the constitution of sovereignty.

Additionally, this example demonstrates the importance of the local goddess in the institution of local sovereignty. Indeed, this phenomenon is ubiquitous in the foundational narratives of the region, with the progenitors of the Hoysalas worshipping Vāsantikādēvi/Padmāvati and those of Vijayanagara worshipping Pampādèvi, the Woḍeyars Cāmuṇ̣ādēvi. The narrative even extends into other regions of South India, such as Madurai, and the deity Mīnākṣi, in which local sovereignty is likewise related to a powerful and martial local goddess. The nature of this relationship, however, is altered as the local kingdom progresses through Kulke's processural stages (Kulke 1998, pp. 233-62; Kulke 2001, pp. 9-10). As the ruler and deity move up the political hierarchy, making claims of overlordship, the political theology is radically altered, with male Purānic deities being incorporated into the courtly 
devotional practice and the local goddess "married" to the imperial male deities, Śiva or Viṣnu. While the local goddess retains the role as the local auctor of earthly sovereignty, the diffusion of the sovereignty from the divine to the earthly realm is renewed through rituals with both the local goddess and the male divine overlord, maintaining both the local devotional practice and incorporating broader Purānic transmissions. The rulers, however, maintain a special relationship with these goddesses as their family deities (kuladevate) and as the source of their local sovereignty, which is renewed through regular and festival worship, and divine election, which is told and retold through royal genealogical literature. In both cases, royal power flows from two directions: for the earthly subordinate ruler, its source is from the local goddess and from the earthly overlord, and for the earthly overlord, royal power comes from the divine overlord but continues from local sources as well.

\subsection{Situating Earthly Sovereignty: Kṣetra and Divine Election}

Within these foundational narratives, we also see the emphasis on the space as it relates to the constitution of sovereignty. ${ }^{27}$ In particular, the initial transfer of sovereignty is authorized and implemented by the deity, who resides in that sacred site of power. Thereafter, the sovereignty of the ruler is linked to that locale, but as they rise through the political hierarchy, that local sovereignty is extended as the deity and the landscape become Purānicized.

In the foundational narratives of Karnataka, a sacred place is connected to a king's sovereignty and his lineage's divine election. The local goddess gives the earthly sovereign the authority to rule over the territory that is under her supernatural protection. Therefore, we can see how these local goddesses operate with sovereignty over a local or regional sacred space, which is often referred to as their pịtha or their kṣetra (Kannada: kșêtra). Village goddesses, or gramadēvates, are perhaps the most well-known of these deities. The locality or situatedness alluded to in their name, grämadevate or "village goddesses", is the central essence of these deities. ${ }^{28}$ Grāmadêvates are situated within and on the outskirts of villages, towns, and cities and rule the metaphysical and physical space under their purview. They are responsible for warding off evil beings, providing good health for the villagers, and invigorating their territory and the human ruler through their powerful energy (śakti). These deities, however, can also be temperamental and require the village to pay their respects through sacrifice or their benevolent protection, and blessing can turn into destruction and malevolence. Local goddesses, however, can also rule over larger extended regions that resemble an expanded role in the cosmo-political hierarchy. Indeed, within the local Jain hierarchies, the regions of southern Karnataka are still divided into zones of sovereignty arranged around the kșetras of their goddesses (e.g., Humca is the center of the Padmāvati kṣetra). Despite typically being outside of normative, public court rituals, in their situated role as local and powerful guardians of villages and regions, local goddesses and their devotional traditions were part of a larger nexus of ritual practice in premodern South India in which chieftains, kingdoms, and lineages aligned themselves with local fierce goddesses who granted energy (śakti) to invigorate their realm and its rulers. In this way, a lineage's initial sovereignty and divine election are situated within their local devotional landscape.

Noticing the many links between devotional sacred spaces and royal territory, Kulke is one of the few scholars of Indian history to speculate concerning the connection between $k$ șetra (region, specifically devotional territory) and kșatra (power or supremacy) (Kulke 2001, pp. 51-65). He connects the shift in royal ritual programs from the Vedic sacrifice to a devotional milieu during the beginnings of the second millennium $\mathrm{CE}$ with a corresponding development in political theology in which the king was fashioned as the "earthly deputies" and "servitors" of their "state deities" (Kulke 2001, p. 51). ${ }^{29}$ He further points out that along with this shift in sovereign identity, the ritual programs of the court were expanded to include a variety of sectarian leaders associated with these devotional centers. His theoretical analysis on the relationship between sovereignty and kșetra, however, is curiously and abruptly curtailed with a provocative transition: "This is not the place to 
discuss in detail the question as to whether the new medieval kingship ideology reflected the spatial dimension which emanated from the holy kṣetra and their deities or whether their sacred sphere grew simultaneously with the process of early medieval state formation" (Kulke 2001, p. 51). To my knowledge, Kulke never returned to this reflection on devotional territory in the development of sovereignty in medieval India, but I believe it is critical for understanding the development of political theology in medieval South India, because it gives us insights into the ways that kings and their courts viewed sovereignty within a cosmic hierarchy in which divine and earthly sovereigns were triangulated into a system of power, authority, and sovereignty through a devotional framework.

The immediacy in the relationship between the ruler and these fierce local goddesses and their local sectarian leaders complicates the question of the broader political theology of the imperial state. This local relationship between divine and earthly sovereigns was not concerned with the ability of the deity to offer liberation or control the cosmos. Instead, it was an alliance that focused on the power of the goddess to bring swift rewards as a result of offerings and devotion. This reflects the immediate needs of the subordinate ruler, who could not aspire to be the earthly overlord but only wished to procure localized sovereignty and territory through divine election and decisive military action.

However, in the transition from local sovereign to imperial power-when the subordinate ruler eventually replaced their imperial overlords, becoming overlords themselveslocal goddess, royal genealogies, and their local realm were subsequently Purānicized through the burgeoning genre of sthalapurāna (local mythic history). ${ }^{30}$ The two royal systems - from the bottom and the top-were merged, and the importance of the situated locality and immediacy of local goddess traditions was worked into the cosmologically significant Purānic time of the regional courtly worldview. As the subordinate rulers emerged as new regional overlords and their local deities were Purānicized, the kings and their courts more often than not did not rely on the soteriological power of the goddesses; instead they chose Vaiṣnava and Śaiva bhakti paths for spiritual progress. ${ }^{31}$ Local goddess traditions, however, were never removed from the royal devotional, and kings and their court continued to understand the origins of their sovereignty through its original transfer and the authority granted by their local goddess, which was renewed through rituals such as Navarātri/Dasara.

Part of the refashioning of locality within the imperial political theology involved re-mapping the landscape of the Purānas, placing the events of the cosmological past within the landscape of local geography. In this process, we can see the relationship between state and hierarchy within the cosmological and terrestrial realms as reflections of one another in which metaphysical and physical theories of territory and overlordship were formed in dialogue with one another and as negotiations between political-courtly devotional-theological institutions. The Purānic system of polity in South India conceptualized territory through theories of cosmological space and time gleaned from the epics and Purānas. The Purānic narratives shaped the way the cosmos and sovereignty were understood within these texts, with the divine and human realms forming one continuum in which cosmic and divine territories were simultaneously mapped in relation to one another. One concrete manifestation of the simultaneity of court and cosmos can be seen in the southern innovation of large royal temple complexes (e.g., Bṛhadeśvara in Tañjāvūr) that reconfigured physical and devotional cartography by centering the courtly and cosmological map through the installation of the abode of the deity within the seat of the king: mapping Mount Meru onto the capital.

The construction of a Purānic framework in medieval South India also redrew mythic cartography within the region through the localization of Purānic narratives (see Inden 1990, pp. 256-62). This was accomplished through the creation of local sthalapurānas, a literary genre that developed along with vamśāvali and that repositioned Purānic history within the landscape of South India. The geography of the Purānas was systemized in dialogue with local devotional traditions within royal courts, which provided the foundation for how they viewed their territorial sovereignty in relation to their divine overlord. Indeed, 
Daud Ali has argued that this spatial orientation was critical in anchoring the realm within the broader cosmo-political structure:

The entire cosmos, both spatially and temporally, was the expression or realization of a divine order anchored ontologically or soteriologically in the being of Lord Viṣnu (or Śiva). Lordship was not concentrated in the being of Viṣnu or Śiva alone, but extended, like the very being of these gods (either as an infusion or as an ontological sharing) throughout cosmos. All worldly agencies were in fact conceived of as the capacities of greater and lesser lordships anchored in the agency of the supreme lord. Lordship belonged properly to the very ontological order of things; it was not an external adjunct to an already present cosmic structure. (Ali 2009, p. 123)

The power of the king to order the realm was derived directly from his direct association with the power of the divine overlord and the order of the cosmos. In order for this cosmic connection to work, the king and his kingdom had to be placed in a descending chain of sovereignty within close proximity to Viṣnu and Śiva, literally placing the ruler and his realm under the deity. This was accomplished by placing the local kingdom at the center of Bhāratavarṣa by placing Purānic narratives within their realm and realigning Purānic geography. By making the connection between the local deities and Purānic narratives, the center of the cosmos was repositioned within the local kingdom-from a mythologically idealized land to a landscape that was firmly situated within their realm. Thereby, the earthly overlords of premodern South India placed themselves in a broader and more significant cosmological framework in which their realm was reconfigured as the center of the cosmos, grafting the divine and human realms through mythic narrative.

\subsection{Conquest}

The final aspect of sovereignty found in the narratives of kingship under discussion in this article is the relationship between sovereignty and conquest. There is a sequential order within the narratives - both the Purānic story of Pṛthu and the local story of Dadiga and Mādhava-in which military engagement is necessarily tied to the transfer of sovereignty and initial divine election. Conquest was also part of the royal rituals in which sovereignty was renewed and diffused, such as the medieval digvijaya and Mahānavami, and was central in the contestation and enactment of that sovereignty on many levels. Therefore, it is important that conquest is considered as a fundamental practice within the articulation and performance of premodern Indian political theology.

Indeed, the local fierce and martial goddesses, the goddesses that authorize a ruler's sovereignty within their kṣetra discussed above, were often venerated for their ability to bring about their devotees' victory. This connection between local goddesses and military power has been well established and does not bear fleshing out here (e.g., see Sarkar 2017). Suffice it to say that it seems as though these goddesses often required the blood of the rivals of their chosen ruler, which reflects the devotional relationship within local sovereignty and attempts to extend that influence. In the case of premodern Mysore, it seems likely that this blood debt was fulfilled by removing the noses of captured foes that were returned to the goddess as offerings (Simmons 2016). Perhaps the most explicit reference to the relationship between warfare, a fierce goddess, and the culture of the court in medieval South India is Cōla Kalinkattup Parani, which describes the blood and guts of the battlefield as a banquet for the goddess Kālī and her ghastly courtiers ( $p \bar{e} y)$ (Cayankontar 2006; see also Ali 2000b). Both the nose-cutting practices of Mysore and the feast of the Kālī's demons in Cōla context offer insights into the continued devotional practices between kings and fierce goddesses, but this perspective only offers us part of the broader understanding of the theology of local sovereignty and conquest neglecting the implications for the deities in the cosmic political structures.

The narratives of war, however, demonstrate how conquest was understood in relation to divine election and acquisition of sovereign territory and can further enlighten the relationship between goddesses, rulers, and cosmic political hierarchy. As we have seen in 
the narratives of the institution of both earthly sovereignty in the Purānas and of local royal lineages, conquest is depicted as a necessary reaction to the transfer of sovereignty and the goddess's divine election. ${ }^{32}$ As such, I believe conquest must be read as an enactment of sovereignty and the "state of exception" (see Schmitt 2005; Agamben 2005). By state of exception, I am referring to the Schmittian definition of sovereignty with which Schmitt begins Political Theology: "Sovereign is he who decides on the exception" (2005, p. 5). In the 2005 translation of this work, the translator George Schwab glosses Schmitt's concept of the exception, "a state of exception includes any kind of severe economic or political disturbance that requires the application of extraordinary measures" (Schmitt 2005, p. 5, fn 1). While sovereignty is the ability to create an exception to the rule, enacting economic and political exceptions was the performance of that sovereignty. As mentioned above, grants of tax-free land revenues were one of the most common forms of the exception through which premodern Indian rulers could enact their sovereignty through economic means, and the documentation of these grants in inscriptions often provided the context in which wars were narrated and conquests were told and retold. Warfare and conquest were often intimately tied to these grants, especially regarding temple construction, as they represent another enactment of sovereignty-the restructuring of the political hierarchy.

Warfare and conquest act as a break in the normative political structure. Within the broader trends of warfare described in epigraphic and later genealogical literature, war seems to align with the two major ritual periods of sovereign transaction-that is, initial transfer of sovereignty and the diffusion of that power through succession and within annual royal festivals, such as Mahānavami. The warfare that coincides with the initial transfer of sovereignty, more often than not, is a war of land acquisition and occupation of the capital. Its concerns are local and situated. In the foundational myths of southern Karnataka, we see a similar pattern, as in the case of Dadiga and Mādhava, in which the process includes the new lineage's election, an alliance with the local devotional cult including promises to uphold the tenets of that practice, and a subsequent conquest of the rival kingdom that was previously established in that site. The war that follows this transfer of sovereignty by the authority of the local deity proves the divine election through the "right of conquest", with the new ruler assuming the throne of the previous ruler and his lineage. Through these wars, local, situated sovereign hierarchy remained unmoved, but authority was transferred from one dynasty to the next, often on the pretense of the former ruler's impiety and adharma.

While wars to overthrow previous rulers were important for foundational stories, they were far less common than military expeditions that were associated with the diffusion of sovereignty through succession that was enacted at the coronation of a new king within the dynasty's lineage or at the conclusion of annual royal ritual cycles, like Mahānavami or Dasara. These wars were not enacted for land acquisition but were aimed at plundering and looting on a lower level and on contesting the political hierarchy on the more abstract level (Davis 1999, p. 61). Kings and their armies took special care to loot the courts of the rival kings, recording in inscriptions the royal emblems and accouterment and even important members of the court-including the women from the fallen rival's harem and the most distinguished artists and architects - that were seized in the raid (Tartakov and Dehejia 1984). Richard Davis has noted the significance of this practice: "[T]hey were viewed as physical instantiations of a king's authority, inseparable from his capacity to rule rightfully. Accordingly, appropriating them on the field of battle was equivalent to 'plucking out' the opponent's sovereignty and incorporating it into one's own' (Davis 1999, p. 61). By removing these objects, a king could demonstrate his kingdom's superiority over a rival king, subsuming his sovereignty as subordinate to its own (e.g., Mahipala attempting to take Indra's ornaments from King Padmaprabha or Mahișa taking the gods' Vedic portions). However, as alluded to above, in the foundational narratives, these objects and emblems were also physical embodiments of the divine overlord's sovereignty, the prasāda of their power and authority. Implicit within this practice of appropriation, then, is 
not only a restructuring of the earthly political order, but also a contestation and negotiation of divine supremacy.

The restructuring of the divine sovereign hierarchy can especially be seen in the aggression against temples associated with rival rulers. The most obvious form of this practice is the destruction of temples within enemy territory and their images (mūrti). The temples and their images were intimately linked to the sovereign within whose territory they resided. The Brhatsamhita even associates the destruction of either with the king's loss of sovereignty and even his territory (Davis 1999, p. 53). Therefore, it is no surprise that when kings conquered a rival, along with looting the royal regalia, the armies would attempt to completely nullify the source of their sovereignty (see Eaton 2000, pp. 64-66; and Davis 1999, pp. 82-85). Temple and image destruction was not the only aspect of temple aggression; looting and appropriation of images (mūrti) from the temples were also commonplace in premodern Indian warfare. There are many cases in which inscriptions and texts record the details of the movement of such images, and it even becomes a common trope in South Indian vamśāivali and sthalapurāna literature in which Muslim rulers abscond with a mūrti only to return it after a miraculous intervention. The images taken from temples often reflected the same symbols taken from the court-courtiers (e.g., door guardians) and ritual accouterments-demonstrating the analogy of the divine and earthly courts (cf. Davis 1999, pp. 76-87). Additionally, the deities themselves were often taken from conquered kingdoms and displayed in the capital of the victor within newly constructed temples (e.g., Davis 1999, pp. 65-68; see also Michell 1995, p. 155). In the case of its political theological position, as Inden has said, "[ $t$ ]he building of a temple was, for example, as much an act of war as it was an act of peace, as much a political as it was a religious act;" as victorious kings brought their enemies' gods into the territory of their own, forcing their submission to the divine overlord (1990, p. 230).

By accumulating the royal emblems of their rival kings and by appropriating or destroying the temples and images of their deities, kings and their courts in premodern India used warfare as a means through which the political hierarchy could be contested and conquest as the ultimate enactment of their sovereignty and proof of their divine election.

\section{Conclusions}

To truly understand how sovereignty was conceptualized (i.e., its origins, its transfer, and its diffusion), we must expand our inquiry of premodern Indian kingship to include sources that incorporate narrative enactments of its political theologies. Once this is acknowledged, we can expand our frame of reference to see how premodern Indian courts dealt with issues of the transfer of sovereignty from dynasty to dynasty and how it was diffused from one ruler to the next within a lineage of succession. The devotional nature of kingship and its role in the constitution, institution, and diffusion of sovereignty is evident in the narrative traditions of premodern India in Purānas and royal genealogical literature. In these narratives, we see the self-description of these courts' political theologies and where they envision their rulers within the political hierarchy writ large. At every turn, however, sovereignty is intimately linked with the devotional relationship between the ruler and his local deity, who provided authority through divine election.

From the narrative political theologies from the Purānic tradition or encomia of local and regional kings such as those examined in this article, a new model of traditional Indian emerges that can make sense of this conceptualization of sovereignty within a cosmic hierarchy of gradated and nested relationships of overlords and subordinate (Figure 2). This hierarchy was not divided in terms of divine and earthly sovereignty; instead, both existed within a broader theoretical field in which sovereignty and its authority originated and flowed in various directions. The relationships between sovereigns were navigated through a complex of devotion in which the paradigmatic ritual was püjā. Within this system, sovereignty, as with prasāda, was transferred from overlord to subordinate through the material exchange of objects and emblems that were infused with the surplus sovereignty of the overlord. 


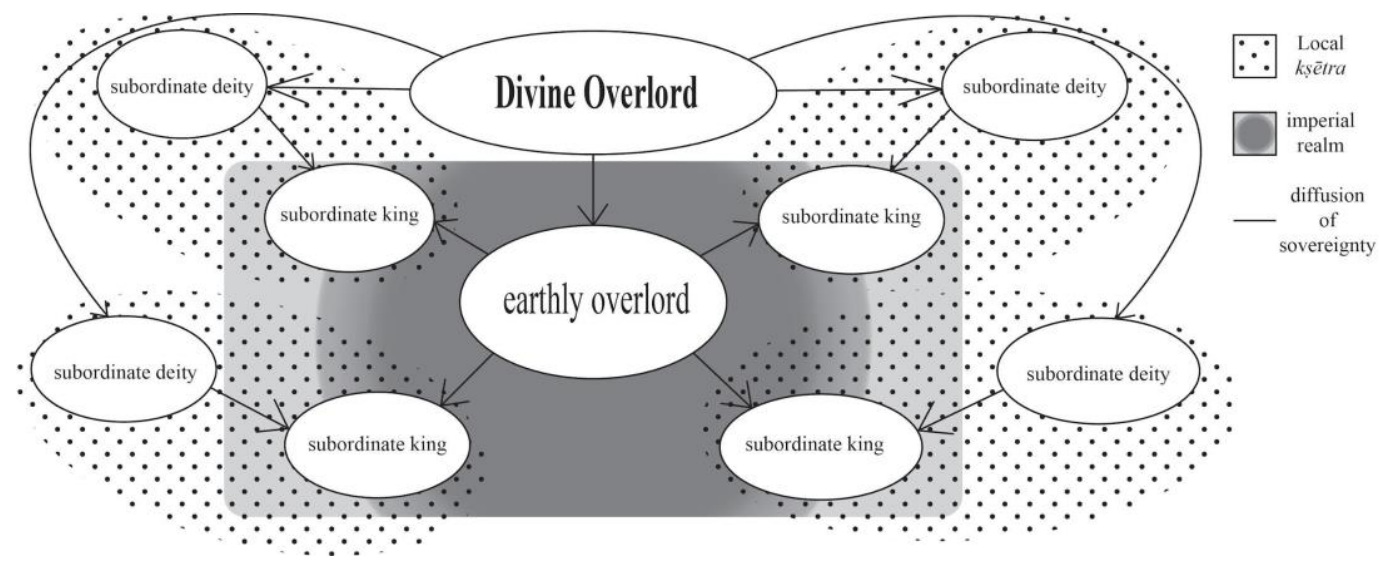

Figure 2. New model of the diffusion of authority and sovereignty ${ }^{33}$.

The resultant ritual political model was not limited to earthly sovereigns, but deities were envisioned within the same network and as sovereigns in their own right, part of a broader cosmological structure. As I have attempted to show in this article, we consider the divine as yet another sovereign within a broader conceptualization of political structure-as I suggest was the case in premodern Indian kingship-which allows us to understand that sovereignty was not separated into spheres of transcendent and immanent reality (cf. Heesterman 1985). Sovereignty, instead, existed within a network of triangulated concerns that negotiated the roles and relationships between earthly and divine sovereigns, both of whom had claims to overlapping domains. In this network, the divine overlord transferred power and authority, its sovereign surplus, to subordinate deities who ruled over physico-spiritual territories (ksetras) and to the earthly overlord/emperor who served (or aspired to serve) as the world-conquering cakravartin. At the earthly level, the subordinate deity authorized a local king to enact earthly sovereignty over their ksetras. Additionally, these subordinate kings were authorized to operate within the broader earthly political system as vassals under the suzerainty of the earthly overlord/emperor. At each level, the transfer of authority and the right to rule was facilitated and ritually enacted by the exchange of emblems and implements that functioned as a form of prasāda, imbued with royal blessings and sovereign surplus. Finally, each of these offices of kingship and sovereignty were dynamic and could undergo restructuring as authority was transferred from one dynasty to the next, usually enacted through conquest.

Funding: This research received no external funding.

Institutional Review Board Statement: Not applicable.

Informed Consent Statement: Not applicable.

Conflicts of Interest: The author declares no conflict of interest.
Abbreviations
EC Epigraphia Carnatica
REC Epigraphia Carnatica Revised Edition
$M A R \quad$ Archeaological Survey of Mysore

\section{Notes}

I use Carl Schmitt's definition as the starting point for my use of "sovereignty". In the first line of his 1922 book Political Theology, Schmitt defines the sovereign as "he who decides on the exception" (2005, p. 5). Schmitt argues that the political authority of the sovereign is prior to and necessary for legal order within a state. For Schmitt, sovereign power that results from political authority is enacted when the ruler decides to break the normative legal order, creating an exception to a rule or law. His broader understanding of the concept of sovereignty and its connection to theological discourse and religious texts and the resulting 
political theory of the god-like king has affinity with premodern Indian notions of sovereignty and the relationship between sovereigns and the divine. Indeed, the rhetorical overlap between deities and kings is astounding in the Indian context from ancient rituals from the Vedic context to medieval inscriptions that eulogize kings as embodiment or manifestations of deities to genealogies that fashion entire dynasties as biological descendants of Kṛṣna, or Rāma, or any other host of mythological and legendary kings and warriors. I, however, do not understand sovereignty as a monolithic category; instead, throughout this book, I attempt to read sovereignty and political authority as multivalent categories that exist in a myriad of nested divine and earthly hierarchies.

2 This premodern concept of cosmic political theology was then carried over into early modernity in the productions of the court, perhaps most evidently in royal history literature (vaṃśāvali) (cf. Rao et al. 1992, pp. 55-56).

3 "Transfer" in this context refers to the initial moment when a being (usually a human) is authorized to rule by the divine sovereign, cosmic or local. This implies that sovereignty over the domain preexisted this newly granted political entitlement (as portion of the overlord's sovereignty or least under the purview of its influence) and that it could be moved from one ruler/lineage to another. Practically, this issue arose when one ruler supplanted the previous ruler or overlord, taking his and his lineage's place in the political structure (i.e., the creation of a new dynasty). The initial transfer of sovereignty is important in the narrative material examined in this article, as it involves siting local sovereignty within complex layers of devotional practice, divine election, and conquest and from which all other forms of sovereignty grow. By diffusion, I refer to the process of renewing sovereignty that was enacted through devotional rituals of exchange (i.e., püjāa, abhiśêka, etc.) or was passed hereditarily within dynastic lineages, both of which were rooted in concerns of dynastic continuity.

4 Indeed, when one surveys the remaining manuscripts from premodern India royal courts and specifically to the manuscript collections and textual references within literature from the Mysore court narrative texts-Purānas, epics, and genealogical texts—seem to have been produced in much greater number within premodern Indian courts than dharmaśāstras or arthaśāstras. Saletore has even claimed that issues of royal interregnum and succession were primarily modeled on narrative texts, especialy the Rāmāyana (Saletore 1963, pp. 135-36).

5 Similarly, Rao et al. (1992) suggested that "the royal assembly invokes the purānic vision of the king as aṃśa, a partial embodiment of the god" and "the servant partially embodies his king" (p. 49).

6 For much a much more detailed discussion of this model, see the introduction to this Special Issue, "Reconsidering Theories of Kingship and its Structure in Premodern India".

7 Inden also falls prey to this at times in his essay, assuming that the earthly kingdoms of Bhāratavarsa were simply "models" or "replicas" of the celestial kingdom of Jambudvipa, instead of gradated examples of the same sovereign structures only with lesser power and reach.

8 For example, in the Śrimmanmahārājavara Vaṃśāvaḷi from the colonial Mysore court, the ministers of the court look to the Kālikā Purāna for guidance concerning Rāja Woḍeyar's inaugural Navarātri and the proper ritual course of action related to the untimely death of his son (Wodeyar 1916, p. 39).

9 A manvantara contains seventy-one yuga cycles. e.g., Kālikā Purāna 26-27; Vāyu Purāna 33; Mārkaṇdēya Purāna 53; Vị̣nu Purāṇa 1.7.

11 They first tried rubbing his left thigh, from which an evil and dark person appeared, who they called Niśāda (a tribal group) and exiled to the Vindhyā mountains.

The text then gives the prophecy that any future cakravartin will similarly be marked with the discus as the sign of divine election. The etymology of $r \bar{a} j a$ is connected with $\sqrt{ } r \bar{a} j$ "to shine". See below.

The first conquest of the narrative can be read as the rebellion of the sages against Vena and could be read as a narrative of the transfer of sovereignty; however, the text instead relates the birth of Prthu to dynastic continuity as he is portrayed as the son of Vena and part of the lineage of Svāyambhu Manu.

15 The discussion is in the form of conversation between four wise birds and the sage Mārkandēya.

16 For an interesting discussion on the relationship between the Dēvī Māhātmya and the broader narrative of the text, see Balkaran (2018) (in Simmons et al. 2018, pp. 23-38).

17 For many examples from the Cāḷkya, Rāṣtrakūṭa, Cōḷa, Western Gañga, Hoysala, Vijayanagara kingdoms, see (Simmons 2014, pp. 83-111; Simmons 2017).

18 This also forms the roots from which the later vaṃśāvali (genealogical literature) tradition emerges.

19 Leslie Orr has recently examined grants from southern Tamilnadu in which the grants are given as orders directly from the deity themselves.

20 The economic, political, and ritual freedom that came along with these grants problematizes Foucault depiction of power in the ancien regime - power over death—and biopolitical power of modernity - power to control life.

21 This inscription seems to be based on a similar inscription from 1112 that was installed in Purale, but the composer has added a few details, especially relating to the emerging Hoysala kingdom (EC VII Sh.64). 
For more on the interesting world of rhetoric claims of sovereignty and their contestation in the Jain and imperial context, see Pierce Taylor (Pierce Taylor 2014).

23 The term used for power here (ậ) is directly related to the Kannada term for king (arasu).

24 The term patțada mahāde $v i$, which literally means "royal goddess" is ambiguous. It could either be a name of his queen or it could refer to the royal goddess Kañcala Dēvi, who was also the royal goddess for the Yādavas of Dēvagiri, his contemporaries in modern day Maharashtra and northern Karnataka.

A parallel political theology exists in Buddhism and Hinduism. For a succinct and poignant discussion of the cakravartin in Buddhism and Jainism, see (Singh 2017, pp. 30-40). Singh (2017) also includes many references to the use of cakravartin in Hindu contexts $(60-61 ; 103-104 ; 206-207)$.

26 I have primarily focused my research on premodern southern Karnataka; however, the narrative of divine election by local goddess and the consequent transfer of sovereignty is not limited to the context of southern Karnataka and is part of many praśastis and vamiśāvalis, such as the Tañjāoūri Andhra Rājula Caritra, the early modern foundational narrative of the Madurai Nāyaka kingdom (see Rao et al. 1992, pp. 49, 55).

Daḍiga and Mādhava's sovereignty is lost when they are forced to leave their kingdom, and as soon as they are made sovereigns again, their spatial territory is immediately defined.

28 In many ways, the situatedness of goddesses has been acknowledged even in the ways devotees speak about sacred sites associated with female deities. Common nomenclature typically refers to sacred sites in general as tìrthas ("ford" or "crossing place"). Important pilgrimage sites relating to goddesses or the Goddess are called pitthas ("seats" or "place"). While this is not a hard and fast rule, the common use of these terms demonstrates the importance of goddesses in their locale and their relationship with the material landscape that they imbue with sacrality and power. The term śakti pitha is most commonly deployed in reference to the sites where the body parts of Satī are said to have fallen as Śiva, her distraught consort, carried her charred remains back to their mountain abode after she immolated herself on her father Dakșa's sacrificial fire in the famous Purānic tale. The site and the surrounding landscape embody the sacred power that imbued the body of the goddess. In many cases, the landscape itself is the embodiment of the anatomy of the sacred: hills are the breasts of the goddess; cleft stones become her yōni; etc. Often these sites are very difficult to reach and prior to modern transportation would require a very arduous pilgrimage. This was also the case at Cāmuṇịi hill until Dodda Dēvarāja Woḍeyar installed the steps leading up the hill to the temple in the 17th century. It is possible that the difficulty of the pilgrimage to these remote shrines associated with goddesses might have something to do with the epithet "Durgā," which means "She who is hard to go to".

Though the results were obviously quite different (i.e., the king becoming a ritual actor in the shift to devotionalism), the transition from Vedic rituals to a devotional deity-centered model in many ways resembles the same process that took place in the ancient constitution of royal authority from endless cycles of ritual kingship to what Heesterman has called "transcendent authority" that was "vested in the Veda, which was fixed and codified as the eternal, not human-made and therefore indisputable" (Heesterman in Richards 1998, pp. 32-33); however, in the case of the latter period that makes up the subject of this book, authority to sanction sovereignty/kingship was displaced unto local and regional deities and their sectarian leaders.

30 The association of local fierce goddesses with the Purānic narratives that I will refer to as Purānicization was unlike the famous theory of Sanskritization first proposed by M. N. Srinivas (2003). Srinivas argued that the incorporation of Sanskrit and brāhmanical customs was a means of social uplift for groups traditionally outside or low within brāhmanically dominated society. Purānicization of the local goddess traditions was not the means of uplift, but it reflected the previous rise in status of local kings who subsequently formed a regular court and employed brāhmana ministers and poets familiar with the conventions of courtly rhetoric and ritual.

31 The evolution of royal devotional practices can be seen in the genealogies of the Wodeyar kingdom of Mysore in the same region of southern Karnataka. This process started with Rajja Woḍeyar (r. 1610-1617), who overthrew the Vijayanagara viceroy in Śrīrangapațana in 1610 and who established Vaiṣnava devotion in the Mysore court; however, it was solidified during the reign of Kanthīrava Narasrāja Woḍeyar (r. 1638-1659), who saved Vijayanagara from an attack by the Bijapura armies and subsequently announced his independence by minting his own coins in 1645. During Kaṇthīrava Narasrāja Woḍeyar's reign, the tension between the Wodeyars' new Vaișnava devotion and their worship of the goddess on the hill (bettada camundi or bețada amma) was resolved in the courtly literature. This can be seen in both the Gajjagahal!i inscription (1639) and the Kanțiñava Narasaräja Vijayam (ca. 1648), wherein the local goddess Cāmuṇ̣i (bețtada camuṇ̣i) was connected to the protection of the Purānic goddess who slays the buffalo demon (mahișāsuramardin̄̄), but the king was said to be devoted to both Viṣnu and Śiva (hariharabhakti) (REC III.Nj 212; KNV 1.10; 7.63).

32 Carl Schmitt has argued that land and conquest are inherently linked, as the latter provides the means through which the former is appropriated in premodern societies (Schmitt 2006, $328 \mathrm{ff}$ ).

33 For much a much more detailed discussion of this model, see the introduction to this Special Issue, "Reconsidering Theories of Kingship and its Structure in Premodern India".

\section{References}

Agamben, Giorgio. 2005. State of Exception. Chicago: University of Chicago Press. 
Ali, Daud. 2000a. Royal Eulogy as World History: Rethinking Copper-plate Inscriptions in Cōla India. In Querying the Medieval: Texts and the History of Practices in South Asia. Edited by Ronald Inden, Jonathan Walters and Daud Ali. New York: Oxford University Press, pp. 165-229.

Ali, Daud. 2000b. Violence, Gastronomy and the Meanings of War in Medieval South India. The Medieval History Journal 3: 261-89. [CrossRef]

Ali, Daud. 2009. Cosmos, Realm and Property in Early Medieval Kingdoms. In Tamil Geographies: Cultural Constructions of Space and Place in South India. Edited by Martha Ann Selby and Indira Viswanathan Peterson. Albany: SUNY Press, pp. 117-41.

Babb, Lawrence A. 1996. Absent Lord: Ascetics and Kings in a Jain Ritual Culture. Berkeley: University of California Press.

Balkaran, Raj. 2018. The Splendor of the Sun: Brightening the Bridge between Mārkaṇdeya Purāna and Devī Māhātmya in Light of Navarātri Ritual Timing. In Nine Nights of the Goddess: The Navarātri Festival in South Asia. Edited by Caleb Simmons, Moumita Sen and Hillary Rodrigues. Albany: SUNY Press, pp. 23-38.

Balkaran, Raj. 2019. The Goddess and the King in Indian Myth: Ring Composition, Royal Power, and the Dharmic Double Helix. New York: Routledge.

Balkaran, Raj. 2020. The Goddess and the Sun in Indian Myth: Power, Presentation and Mirrored Māhātmyas in the Mārkandeya Purāna. New York: Routledge.

Biardeau, Madeleine. 1994. Hinduism: The Anthropology of a Civilization. Delhi: Oxford University Press.

Cayankontar, John Samuel. 2006. Kalinkattup Parani: In English. Silver Jubilee Celebration Series; Chennai: Institute of Asian Studies. Chattopadhyaya, Brajadulal. 1994. The Making of Early Medieval India. Delhi and New York: Oxford University Press.

Cort, John E. 2001. The Jina as King. In Vasantagauravam: Essays in Jainism Felicitating Professor M.D. Vasantha Raj of Mysore. Edited by Jayandra Soni. Mumbai: Vakils Feffer and Simons, pp. 27-50.

Davis, Richard H. 1999. Lives of Indian Images. Princeton: Princeton University Press.

Dirks, Nicholas B. 1993. The Hollow Crown: Ethnohistory of an Indian Kingdom. Ann Arbor: University of Michigan Press.

Dundas, Paul. 1991. The Digambara Jain Warrior. In The Assembly of Listeners: Jains in Society. Edited by Michael Carrithers and Caroline Humphrey. Cambridge: Cambridge University Press, pp. 169-86.

Eaton, Richard M. 2000. Temple Desecration in Pre-Modern India (Part I). Frontline 17: 62-70.

Flueckiger, Joyce Burkhalter. 2017. When the Goddess Speaks Her Mind: Possession, Presences, and Narrative Theology in the Gangamma Tradition of Tirupati, South India. International Journal of Hindu Studies 21: 165-85. [CrossRef]

Frei, Hans W. 1993. Theology and Narrative: Selected Essays. Edited by George Hunsinger and William C. Placher. New York: Oxford University Press.

Heesterman, J. C. 1985. The Inner Conflict of Tradition: Essays in Indian Ritual, Kinship, and Society. Chicago: University of Chicago Press. Inden, Ronald B. 1981. Hierarchies of Kings in Early Medieval India. Contributions to Indian Sociology XV: 99-125.

Inden, Ronald B. 1990. Imagining India. Bloomington: Indiana University Press.

Kulke, Hermann. 1998. The State in India, 1000-1700. Delhi: Oxford University Press.

Kulke, Hermann. 2001. Kings and Cults: State Formation and Legitimation in India and Southeast Asia. New Delhi: Manohar Publishers \& Distributors.

Michell, George. 1995. Architecture and Art of Southern India: Vijayanagara and the Successor States. The New Cambridge History of India, I, 6. Cambridge: Cambridge University Press.

Pargiter, Frederick E., ed. 1913. The Purana Text of the Dynasties of the Kali Age. London: Oxford University Press.

Pierce Taylor, Sarah. 2014. Sovereigns whose Feet Were Worshipped by Kings: The Jain Matha and the Rhetoric of Empire. Paper presented at the AAR, San Diego, CA, USA, November 22-25.

Pierce Taylor, Sarah. 2020. Jains, Kings, and Kingship in Medieval India. In Brill Encyclopedia of Jainism. Edited by John E. Cort, Paul Dundas, Knut A. Jacobsen and Kristi L. Wiley. Leiden: Brill, pp. 486-98.

Rao, Velcheru Narayana, David Shulman, and Sanjay Subrahmanyam. 1992. Symbols of Substance: Court and State in Nāyaka Period Tamilnadu. New York: Oxford University Press.

Richards, John F., ed. 1998. Kingship and Authority in South Asia. Delhi: Oxford University Press.

Saletore, B. A. 1963. Ancient Indian Political Thought and Institutions. Delhi: Asia Publishing House.

Sarkar, Bihani. 2017. Heroic Shāktism: The Cult of Durgā in Ancient Indian Kingship. Oxford: Oxford University Press.

Schmitt, Carl. 2005. Political Theology. Chicago: University of Chicago Press.

Schmitt, Carl. 2006. The Nomos of the Earth in the International Law of the Jus Publicum Europaeum. Translated by G. L. Ulman. New York: Telos Press.

Simmons, Caleb. 2014. The Goddess and the King: Cāmundẹśsari and the Fashioning of the Wodeyar Court of Mysore. Gainesville: University of Florida.

Simmons, Caleb. 2016. The 'Hunt for Noses': Contextualizing the Wodeyar Predilection for Nose-Cutting. Studies in History 32 : $162-85$. [CrossRef]

Simmons, Caleb. 2017. Family, God, and Kingdom: Vạ̣śāvali as Royalist Literature. In Clio and Her Descendants: Essays for Kesavan Veluthat. Edited by Manu Devadevan. New Delhi: Primus Books, pp. 598-622.

Simmons, Caleb. 2020. Devotional Sovereignty: Kingship and Religion in India. New York: Oxford University Press.

Simmons, Caleb, Moumita Sen, and Hillary Rodrigues. 2018. Nine Nights of the Goddess: The Navarätri Festival in South Asia. Albany: SUNY Press. 
Singh, Upinder. 2017. Political Violence in Ancient India. Cambridge: Harvard University Press.

Srinivas, Mysore Narasimhachar. 2003. Religion and Society among the Coorgs of South India. Delhi: Oxford University Press.

Stein, Burton. 1980. Peasant State and Society in Medieval South India. Delhi: Oxford University Press.

Stein, Burton. 2010. A History of India. Sussex: Wiley-Blackwell.

Subbarayalu, Y. 1982. The Cōla State. Studies in History IV: 265-306.

Tartakov, Gary Michael, and Vidya Dehejia. 1984. Sharing, Intrusion, and Influence: The Mahișāsuramardinī Imagery of the Calukyas and the Pallavas. Artibus Asiae 45: 287-345. [CrossRef]

Willis, Michael. 2009. The Archaeology of Hindu Ritual: Temples and the Establishment of the Gods. New York: Cambridge University Press. Woḍeyar, Mummadi Krsnarāja. 1916. Maisūru Samsthānada Prabhugalu Śrīmanmahārājavara Vamíāoali or the Annals of the Mysore Royal Family. Mysore: Government Branch Press.

Yelle, Robert. 2010. The Trouble with Transcendence: Carl Schmitt's 'Exception' as a Challenge for Religious Studies. Method E Theory in the Study of Religion 22: 189-206. 